\title{
Knock-down of hypoxia-induced carbonic anhydrases IX and XII radiosensitizes tumor cells by increasing intracellular acidosis
}

\author{
Jérome Doyen ${ }^{1,2}$, Scott K. Parks ${ }^{1}$, Serge Marcié ${ }^{2}$, Jacques Pouysségur ${ }^{1,3}$ and Johanna Chiche ${ }^{1}$ * \\ 1 Institute for Research on Cancer and Aging of Nice, CNRS UMR 7284, University of Nice Sophia-Antipolis, Nice, France \\ ${ }^{2}$ Department of Radiation Oncology, Centre Antoine-Lacassagne, Nice, France \\ ${ }^{3}$ Centre Scientifique de Monaco, Monaco
}

\section{Edited by:}

Lorenzo Galluzzi, Institut National de la Santé et de la Recherche Medicale, France

\section{Reviewed by:}

Silvia Pastorekova, Slovak Academy of Sciences, Slovakia

lan Kunkler, University of Edinburgh, UK

Brad Wouters, Ontario Cancer Institute, Canada

\section{${ }^{*}$ Correspondence:}

Johanna Chiche, INSERM U 1065 Centre Méditerranéen de Médecine Moléculaire, Team 3 "Metabolic control of cell deaths," 151 Route de Saint Antoine de Ginestière, BP 2 3194, 06204 Nice Cedex, France. e-mail: chiche@unice.fr
The relationship between acidosis within the tumor microenvironment and radioresistance of hypoxic tumor cells remains unclear. Previously we reported that hypoxia-induced carbonic anhydrases (CA) IX and CAXII constitute a robust intracellular $\mathrm{pH}\left(\mathrm{pH}_{\mathrm{i}}\right)$-regulating system that confers a survival advantage on hypoxic human colon carcinoma LS174Tr cells in acidic microenvironments. Here we investigate the role of acidosis, CAIX and CAXII knock-down in combination with ionizing radiation. Fibroblasts cells (-/+ CAIX) and LS174Tr cells (inducible knock-down for ca9/ca12) were analyzed for cell cycle phase distribution and survival after irradiation in extracellular $\mathrm{pH}_{\circ}$ manipulations and hypoxia $\left(1 \% \mathrm{O}_{2}\right)$ exposure. Radiotherapy was used to target ca9/ca12-silenced LS174Tr tumors grown in nude mice. We found that diminishing the $\mathrm{pH}_{\mathrm{i}}$-regulating capacity of fibroblasts through inhibition of $\mathrm{Na}^{+} / \mathrm{H}^{+}$exchanger 1 sensitize cells to radiation-induced cell death. Secondly, the $\mathrm{pH}_{i-}$ regulating function of CAIX plays a key protective role in irradiated fibroblasts in an acidic environment as accompanied by a reduced number of cells in the radiosensitive phases of the cell cycle. Thirdly, we demonstrate that irradiation of LS174Tr spheroids, silenced for either ca9 or both ca9/ca12, showed a respective 50 and $75 \%$ increase in cell death as a result of a decrease in cell number in the radioresistant $\mathrm{S}$ phase and a disruption of CA-mediated $\mathrm{pH}_{\mathrm{i}}$ regulation. Finally, LS174Tr tumor progression was strongly decreased when ca9/ca12 silencing was combined with irradiation in vivo. These findings highlight the combinatory use of radiotherapy with targeting of the $\mathrm{pH}_{\mathrm{i}}$-regulating $\mathrm{CAs}$ as an anti-cancer strategy.

Keywords: carbonic anhydrases, hypoxia, intracellular $\mathrm{pH}$, ionizing radiation, tumor growth

\section{INTRODUCTION}

Ionizing radiation is used therapeutically to induce cancer cell death, decrease distant metastasis rates, and to increase overall patient survival (Darby et al., 2011). However, radiotherapy does not efficiently target all cells of the tumor mass. Tumor cell re-population and activation of DNA repair mechanisms (ATM, $\gamma \mathrm{H} 2 \mathrm{AX}$, and $\mathrm{p} 53)$ are key components of tumor cell radioresistance (Huen and Chen, 2008). Cells in the G2/M and G1 phases of the cell cycle have been shown to be the most radiosensitive, while cells in the $\mathrm{S}$ phase are radioresistant (Hwang et al., 2000; Pawlik and Keyomarsi, 2004). The latter is attributed to DNA double strand breaks (DSBs) repair systems such as homologous recombination that occur in the S phase (Kastan and Bartek, 2004; Jackson and Bartek, 2009). In the 1950s, several groups established the connection between hypoxia and radioresistance in mammalian tumors (Deschner and Gray, 1959; Dewey, 1960) and oxygen levels remain the major cell radiosensitizer known to date. In well-oxygenated conditions, the free radicals generated by ionizing radiation insult react with $\mathrm{O}_{2}$ to form peroxy radicals that damage DNA much more efficiently than reduced free radicals (Brown, 2007). Consequently, the poorly oxygenated (hypoxic) cells of tumors are more radioresistant (Gray, 1953). These studies led to the general hypothesis that oxygen acts at a physicochemical level to improve radiation induced damage as a consequence of the high affinity between the oxygen molecule and the unpaired electron on the free radical produced by radiation.

In addition to low oxygen, increased acidification is also a hallmark of hypoxic tumors and it has been suggested to play an indirect role in the poor radioresponse of hypoxic tumors (Vaupel, 2004). In contrast, another report indicates that extracellular acidosis may enhance radiosensitivity in combination with lactate accumulation for certain cell lines (Grotius et al., 2009). However, lactate accumulation alone (in the absence of $\mathrm{pH}$ disruption) has also been suggested to reduce radiosensitivity of tumor cells (Quennet et al., 2006). Furthermore, the effect of intracellular pH $\left(\mathrm{pH}_{\mathrm{i}}\right)$ and extracellular $\mathrm{pH}\left(\mathrm{pH}_{\mathrm{o}}\right)$ regulation on the efficacy of irradiation remains to be clarified.

Despite the fact that all mammalian cells are capable of protecting their cytosol from acidification through expression of membrane located transporters and exchangers including the $\mathrm{Na}^{+} / \mathrm{H}^{+}$exchanger 1 (NHE-1; Pouysségur et al., 1985) and the monocarboxylate transporter 1 (MCT1; Halestrap and Price, 
1999), hypoxic tumor cells have developed additional mechanisms to regulate their $\mathrm{pH}_{\mathrm{i}}$ (Chiche et al., 2010b). In solid tumors, membrane-bound carbonic anhydrases (CA) IX and XII are controlled by oxygen levels via the hypoxia-inducible factor (HIF-1; Wykoff et al., 2000) and catalyze at the cell surface the reversible hydration of carbon dioxide $\left(\mathrm{CO}_{2}\right)$ into a proton $\left(\mathrm{H}^{+}\right)$and bicarbonate $\left(\mathrm{HCO}_{3}^{-}\right)$. Once generated, $\mathrm{HCO}_{3}^{-}$is proposed to be rapidly taken up into the cell through the $\mathrm{Na}^{+}-\mathrm{HCO}_{3}^{-}$cotransporters (NBC; Romero et al., 2004; Parks et al., 2011) to sustain a slightly alkaline $\mathrm{pH}_{\mathrm{i}}$ compatible with cell survival (Morgan et al., 2007; Swietach et al., 2009; Chiche et al., 2010a). Many reports correlate CAIX expression with poor patient survival in a variety of cancers (see review Supuran, 2008; Chiche et al., 2010a). The extracellular location of the CAIX active site together with its overexpression in hypoxic cancer cells compared to minimal expression in healthy cells, except in the gastro-intestinal tract and the stomach (Pastoreková et al., 1997) makes hypoxia-induced CAIX an accessible target for new anti-cancer therapy (Supuran, 2008; Morris et al., 2011). CAIX function has been clearly established to contribute to extracellular acidification (Svastová et al., 2004). In addition, studies in our laboratory have characterized CAIX and CAXII as robust $\mathrm{pH}_{\mathrm{i}}$-regulating enzymes and have provided evidence that both CAIX and CAXII hold potential as new anti-cancer targets (Chiche et al., 2010a).

We analyzed the downstream effects of CAIX and CAXII activity on radiation-induced cell death to determine whether a combined therapy of irradiation and down-regulation of CAIX and CAXII would sensitize hypoxic cells to ionizing radiation. An alteration in $\mathrm{pH}_{\mathrm{i}}$ regulation (either by inhibition of NHE-1 or expression of CAIX) revealed a decreased percentage in cells found in the radioresistant $S$ phase and an in vitro radiosensitization that correlated with an increase in cell death. Gene silencing of ca9 and $c a 9 / c a 12$ revealed in vitro and in vivo radiosensitization as a consequence of a reduction of cells in the $S$ phase and a decrease in the $\mathrm{pH}_{\mathrm{i}}$-regulating capacity of the cell.

\section{MATERIALS AND METHODS CELL CULTURE AND HYPOXIC EXPOSURE}

Chinese hamster lung CCL39 fibroblasts (ATCC), CCL39-derived PS120 cells lacking NHE-1, and CAIX and CAXII, were cultured as described. Colon adenocarcinoma LS174Tr cells expressing the tetracycline (Tet) repressor were maintained in Dulbecco's modified Eagle's medium (DMEM) supplemented with 10\% fetal calf serum (FCS) and blasticidin $(10 \mu \mathrm{g} / \mathrm{ml}$, Invitrogen). Incubation in hypoxia at $1 \% \mathrm{O}_{2}$ was carried out at $37^{\circ} \mathrm{C}$ in $95 \%$ humidity and $5 \% \mathrm{CO}_{2} / 94 \% \mathrm{~N}_{2}$ in a sealed anaerobic workstation (Ruskinn).

\section{CELL IRRADIATION}

Irradiation of normoxic cells was performed in $25 \mathrm{~cm}^{2}$ ventilated flasks (Nunc), while irradiation of hypoxic cells was performed in $25 \mathrm{~cm}^{2}$ non-ventilated flasks to maintain $1 \% \mathrm{O}_{2}$ during treatment after removal from the hypoxic workstation. Cells were irradiated $100 \mathrm{~cm}$ from the source with a bolus of $1.1 \mathrm{~cm}$ (under dishes). High energy photons were used ( $6 \mathrm{MV})$, delivered by a linear accelerator (PRIMUS ${ }^{\circledR}$, Siemens) with a $40 \mathrm{~cm} \times 40 \mathrm{~cm}$ posterior field. The dose rate of the PRIMUS was 300 monitor units/min and 2 Gy corresponded to 93 monitor units (18.6 s). Spheroids were irradiated with the same schedule but with an anterior field and a bolus placed at the top of the dishes.

\section{PLASMIDS}

Full-length human ca9 cDNA was obtained and inserted into pTREX-A (pcDNA4/TO/myc-His A; Invitrogen; pca9) as described (Chiche etal., 2010a). The short-hairpin (sh) RNAca9 (shca9) was obtained with oligonucleotides: forward 5'AGTTAAGCCTAAATCAGAA-3' and reverse 5'TTCTGATTTAGGCTTAACT-3' and inserted into either pTER vector (also named shca9). Lentivirus particles for two independent sequences (\#1 and \#2) of pLKO.1-Puro shRNA targeting $c a 12\left(\mathrm{cal}^{-}\right)$and nontarget shRNA (ctl; Sigma, TRCN0000116249, TRCN0000116251, and $\mathrm{SHC002V)}$ were used to constitutively silence $\mathrm{ca} 12$.

\section{STABLE TRANSGENIC CELLS}

PS120 cells were transfected with pca9 as described (Chiche et al., 2010a). Tet (10 $\mu \mathrm{g} / \mathrm{ml})$-inducible LS174Tr cells silenced for ca9 (LS-sh ca9/ctl) combined with a constitutive silencing of ca12 (LSshca9/ca12-) were obtained as described (Chiche et al., 2010a).

\section{IMMUNOBLOTTING}

Cells were lysed in $1.5 \times$ SDS sample buffer. Proteins $(40 \mu \mathrm{g})$ were separated on $7.5 \%$ SDS polyacrylamide gels and transferred onto polyvinylidene difluoride membranes (Millipore). Membranes were blotted with the M75 antibody to CAIX (Bayer), a polyclonal antibody to recombinant CAXII (Sigma), p21 (Santa Cruz), $\beta 1$ integrin (Cell Signalling), and Hsp90 (Abcam). Immunoreactive bands were detected with a horseradish peroxidase-antimouse or anti-rabbit antibody (Promega) by ECL (Amersham Biosciences).

\section{CELL CYCLE ANALYSIS}

Cells $\left(3 \times 10^{5}\right)$ exposed to normoxia or hypoxia were washed in PBS and fixed in ice-cold $70 \%$ ethanol for a minimum of $30 \mathrm{~min}$. Cells were centrifuged, washed in $38 \mathrm{mM}$ sodium citrate ( $\mathrm{pH} 7.4$ ), and stained for $20 \mathrm{~min}$ at $37^{\circ} \mathrm{C}$ with $50 \mu \mathrm{g} / \mathrm{ml}$ propidium iodide (Sigma) and $5 \mu \mathrm{g} / \mathrm{ml}$ RNase A (Sigma) in sodium citrate solution. Cell cycle analysis was done by flow cytometry using a FACScan calibur (Becton Dickinson). The proportion of G1, G2/M peaks, and the $S$ phase plateau were calculated with WinMD2 software.

\section{MEASURE OF RADIATION-INDUCED CELL DEATH}

Fibroblasts $\left(1 \times 10^{4}\right)$ were seeded onto $60 \mathrm{~mm}$ dishes. Once attached the medium was replaced by either $\mathrm{HCO}_{3}^{-}$-free or $10 \mathrm{mM}$ $\mathrm{HCO}_{3}^{-}$-containing DMEM buffered at an extracellular $\mathrm{pH}$ (also named outside $\mathrm{pH}, \mathrm{pH}_{\mathrm{o}}$ ) of 7.0 (30 mM MES) or at $\mathrm{pH}_{\mathrm{o}} 7.5$ (30 mM HEPES), supplemented with 10\% dialyzed serum, hypoxanthine $0.1 \mathrm{mM}$, and uridine triphosphate $0.1 \mathrm{mM}$ for growth in the absence of $\mathrm{CO}_{2} / \mathrm{HCO}_{3}^{-}$and transferred to a $\mathrm{CO}_{2}$-free atmosphere for $24 \mathrm{~h}$ in the presence or absence of inhibitors [NHE-1 inhibitor HOE\#694 (Hoechst) $100 \mu \mathrm{M}$ ]. Dishes were then irradiated $(0,2,4,6,8$, and $10 \mathrm{~Gy})$. After irradiation, dishes were returned to $5 \% \mathrm{CO}_{2}$ in regular $\mathrm{NaHCO}_{3}$-containing medium for 5 days. Cells were then trypsinized and the percentage of cell death was determined with trypan blue. 


\section{CLONING EFFICIENCY}

LS174Tr cells were plated in clonogenic conditions (1000 cells per plate, triplicate) in $25 \mathrm{~cm}^{2}$ ventilated flasks during $24 \mathrm{~h}$, then exposed to hypoxia $\left(1 \% \mathrm{O}_{2}\right)$ for $48 \mathrm{~h}$, and subsequently closed with non-ventilated flask caps before irradiation $(0,1,2,4,6$, and $8 \mathrm{~Gy})$. Cells were then returned to normoxic conditions to allow cell recovery and determination of colony number following irradiation. PS120 cells were plated onto $60 \mathrm{~mm}$ dishes in clonogenic conditions (1000 cells per dish, duplicate). Once attached, cells were exposed to $30 \mathrm{mM}$ HEPES, $100 \mu \mathrm{M}$ hypoxanthine, $100 \mu \mathrm{M}$ uridine, and 10\% dialyzed FCS medium adjusted to two different extracellular $\mathrm{pH}$ (either $\mathrm{pH}_{\mathrm{o}} 7.0$ or 7.5 ) in a $\mathrm{CO}_{2} / \mathrm{HCO}_{3}^{-}$free environment and subsequently irradiated $(0$, $1,2,4,6$, and $8 \mathrm{~Gy}$ ) in these environments. Following irradiation, the medium were replaced by a regular medium. Six days (for PS120 cells) or 10 days (for LS174Tr cells) following irradiation, cells were fixed, stained with Giemsa, and counted using Image ${ }^{\circledR}$ software. Of note for both LS174 and PS120 cells, irradiation was not performed but after two or three cell divisions. This raises the possibility of microcolony formation and overestimation of the number of colonies, however, we used caution to exclude microcolonies from our final analysis. Furthermore, our calculations involve a ratio between experimental clones and control. Therefore, the absolute number of clones is normalized because every condition grows with the same amplitude of error.

\section{CELL PROLIFERATION IN THREE-DIMENSIONS AND IRRADIATION OF SPHEROIDS}

To grow spheroids, $2 \times 10^{3}$ cells were seeded in drops in $20 \mu \mathrm{l}$ of $\mathrm{HCO}_{3}^{-}$-free DMEM buffered with $30 \mathrm{mM}$ HEPES pH 7.7 containing $10 \%$ FCS. After 8 days, spheroids were irradiated $(0,2,4$, 6 , and $8 \mathrm{~Gy}$ ) as described above. Intact spheroids were then transferred to polyhema-coated 96-well plates for continued growth in the same respective media for 4 days (12 days total growth time including irradiation). Spheroids were dissociated in Accutase (Life Technologies) and living and dead cells were immediately counted using trypan blue exclusion.

\section{NUDE MICE XENOGRAFTS AND IRRADIATION OF MOUSE TUMORS}

Cells $\left(1 \times 10^{6}\right)$ were subcutaneously injected into the flanks of 4-week-old male athymic nude mice (Harlan) according to CNRS institutional guidelines and tumor growth was measured as reported previously (Chiche et al., 2010a). A total of $750 \mu \mathrm{g} / \mathrm{ml}$ doxycycline (DOX; Sigma) was added in the drinking water before the injection of tumor cells following the previously established protocol in our laboratory allowing us to obtain $90 \%$ of ca9 silencing in vivo (see Chiche et al., 2010a) for immunohistochemical analysis of inducible ca9 silencing in this model). Tumors of $4-5 \mathrm{~mm}$ were irradiated (8 Gy) with contact Xrays (Gérard et al., 2011) using a RT 50 Phillips unit delivering a $50-\mathrm{kV}$ maximal energy $\mathrm{X}$-ray beam. The source-surface distance was $40 \mathrm{~mm}$ and the dose rate was $20 \mathrm{~Gy} / \mathrm{min}$. The X-ray tube was handheld and the precision was controlled through direct vision by the radiation oncologist using a $20-\mathrm{mm}$ diameter applicator. The dose was prescribed at the exit surface of the applicator. One single fraction of 8 Gy was delivered into the visible lesion.

\section{STATISTICAL ANALYSIS}

The Student's $t$-test was used wherein $P$-values of $<0.05$ were considered significant.

\section{RESULTS}

\section{INHIBITION OF THE MAJOR pH 1 -REGULATING SYSTEM NHE-1} SENSITIZES CELLS TO RADIATION-INDUCED CELL DEATH

The contribution of intracellular acidosis to cell radiosensitivity was studied on fibroblasts growing in $\mathrm{pH}_{\mathrm{O}} 7.5$ or a more acidic $\mathrm{pH}_{\mathrm{o}} 7.0$ medium, in the presence or in the absence of NHE-1 inhibitor. We choose to work at $\mathrm{pH}_{\mathrm{o}}$ of 7.0 as it is low enough to reduce the $\mathrm{pH}_{\mathrm{i}}$ compared to the $\mathrm{pH}_{\mathrm{i}}$ obtained at $\mathrm{pH}_{\mathrm{o}}$ of 7.5 but is not low enough to prevent an observation of radiosensitization in acidic conditions due to a reduction in cell viability caused by acidosis alone. The impact of inhibiting $\mathrm{NHE}-1$ on $\mathrm{pH}_{\mathrm{i}}$ regulation in these cells has been well established with NHE-1 inhibition causing a significant reduction in $\mathrm{pH}_{\mathrm{i}}$ in a $\mathrm{pH}_{\mathrm{O}}$ of 7.0 (Pouysségur et al., 1984). Prior to irradiation, we determined the effect of NHE1 inhibition on cell cycle phase distribution. Selective inhibition of NHE-1 using HOE\#694 (100 $\mu$ M; see Masereel et al., 2003 for a review of NHE inhibitors and $\mathrm{HOE} \# 694$ effectiveness) at the more acidic $\mathrm{pH}_{\mathrm{O}} 7.0$ condition reduced the percentage of CCL39 cells in the most radioresistant $\mathrm{S}$ phase (34\% decrease of cells in the radioresistant $\mathrm{S}$ phase in the presence of HOE\#694 compared to non-treated cells) while it had no effect in a more neutral $\mathrm{pH}_{\mathrm{o}}$ 7.5 medium (Figure 1A). Consistent with this finding, irradiation of NHE-1-inhibited fibroblasts in a $\mathrm{pH}_{\mathrm{o}} 7.0$ medium led to an increase in cell death ( $57 \%$ for $10 \mathrm{~Gy}$ ) compared to either untreated cells (35\% for $10 \mathrm{~Gy}$; Figure 1B) or cells exposed to a $\mathrm{pH}_{\mathrm{o}} 7.5$ medium treated or not with HOE\#694 (32\% for $10 \mathrm{~Gy}$; Figure 1C).

\section{EXPRESSION OF THE HYPOXIA-INDUCED $\mathrm{pH}$-REGULATING CARBONIC ANHYDRASE IX PROTECTS CELLS AGAINST IRRADIATION}

We have previously demonstrated that expression of catalytically active CAIX in NHE-1-deficient CCL39 fibroblasts (PS120 cells) maintains a higher $\mathrm{pH}_{\mathrm{i}}$ compared to control PS120 cells lacking CAIX, when cells were exposed to a nominally bicarbonate free acidic medium (Chiche et al., 2010a). Here we showed that in the condition where CAIX is required for $\mathrm{pH}_{\mathrm{i}}$ regulation $\left(\mathrm{pH}_{\mathrm{o}} 7.0\right.$ compared to $\mathrm{pH}_{\mathrm{o}} 7.5$ medium), expression of CAIX in PS120 cells (PS120-pca9) maintains the distribution of the cell cycle phases, while in the absence of CAIX, PS120-pev cells demonstrate a 35\% reduction in the most radioresistant $S$ phase (Figure 2A). Consequently, control PS120-pev cells growing at $\mathrm{pH}_{\mathrm{o}} 7.0$ were shown to be more radiosensitive than PS120-pca9 cells, with $70 \%$ cell death following irradiation of 10 Gy for PS120-pev cells compared to $37 \%$ for PS120-pca9 cells (Figure 2B). Of note, PS120-pca9 cells irradiated with $10 \mathrm{~Gy}$ at $\mathrm{pH}_{\mathrm{o}} 7.0$ exhibited similar cell death rates to that at $\mathrm{pH}_{\mathrm{o}} 7.5$ while PS120-pev cells had much higher cell death at low $\mathrm{pH}_{\mathrm{o}}$ (Figures 2B,C). Thus, active CAIX protects cells against ionizing irradiation at low $\mathrm{pH}$. To definitively validate that the $\mathrm{pH}_{\mathrm{i}}$-regulating functions of CAIX are indeed involved in cellular radioprotection, PS120-pev and PS120-pca9 cells were exposed to a $\mathrm{pH}_{\mathrm{o}} 7.0$ medium containing $10 \mathrm{mM} \mathrm{HCO}_{3}^{-}$. This 


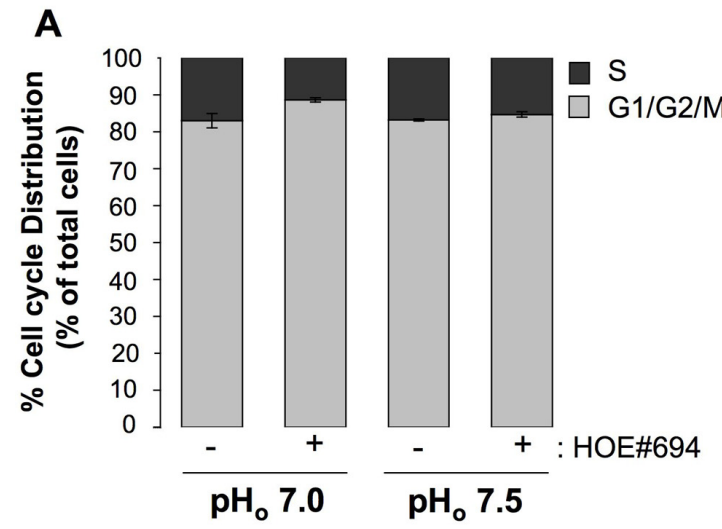

FIGURE 1 | NHE-1 protects cells against irradiation-induced cell death in an acidic environment. (A) Cell cycle distribution of CCL39 cells treated $(+)$ or not (-) with $100 \mu \mathrm{M}$ of the NHE-1 inhibitor (HOE\#694) in normoxia in a $\mathrm{HCO}_{3}^{-} / \mathrm{CO}_{2}$-free environment at $\mathrm{pH}_{0} 7.5$ or 7.0 for $24 \mathrm{~h}$. (B,C) CCL39 cells

$\left(1 \times 10^{4}\right)$ were plated in $60 \mathrm{~mm}$ dishes. Once attached cells were incubated in

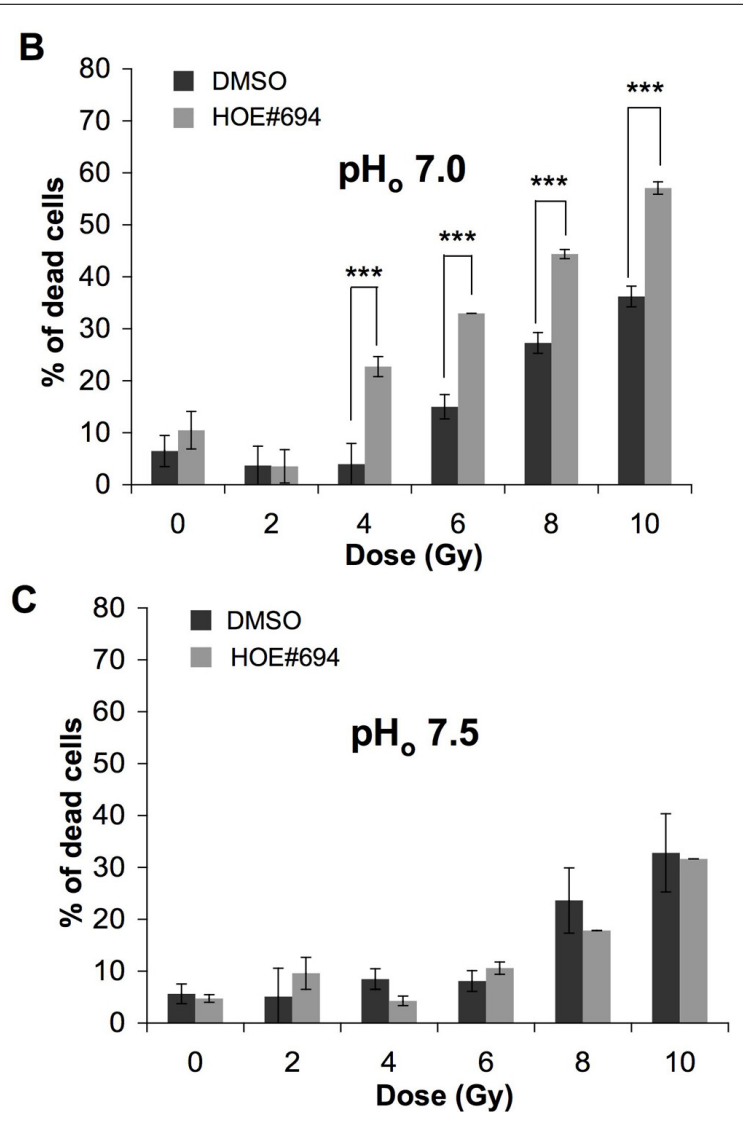

a $\mathrm{HCO}_{3}^{-}$-free medium adjusted to $\mathrm{pH}_{\mathrm{O}} 7.5$ or 7.0 , and treated in the presence $(+)$ or absence (-) of $100 \mu \mathrm{M}$ of NHE-1 inhibitor (HOE\#694) for $24 \mathrm{~h}$ in a $\mathrm{CO}_{2}$-free atmosphere. Dishes were then irradiated $(0,2,4,6,8$, and $10 \mathrm{~Gy})$ and returned to a $5 \% \mathrm{CO}_{2}$ incubator with fresh $\mathrm{HCO}_{3}^{-}$-containing medium for 4 days. Cell death was determined by the trypan blue exclusion assay.
$\mathrm{HCO}_{3}^{-}$addition has been shown previously to maintain $\mathrm{pH}_{\mathrm{i}}$ in acidic $\mathrm{pH}_{\mathrm{o}}$ environments (Chiche etal., 2010a). Irradiation of PS120-pev cells in the presence of $\mathrm{HCO}_{3}^{-}$reduced the percentage of cell death to that obtained for PS120-pca9 cells in a $\mathrm{pH}_{\mathrm{o}}$ 7.0 medium (Figure 2D). Cloning efficiency experiments also confirm the capacity of irradiated cells to survive and recover following irradiation. From 4 to 8 Gy single doses of ionizing radiation of PS120-pev cells exposed to a $\mathrm{pH}_{\mathrm{o}} 7.0$ medium drastically reduced the cloning efficiency, compared to that observed in a $\mathrm{pH}_{\mathrm{o}} 7.5$ medium (Figure 2E, left panel). In contrast, PS120-pca9 cells exposed to a $\mathrm{pH}_{\mathrm{o}} 7.0$ medium were capable to recover after irradiation, to the same extent that we observed in a $\mathrm{pH}_{\mathrm{o}} 7.5$ (Figure 2E, right panel). Taken together these results suggest that the $\mathrm{pH}_{\mathrm{i}}$ regulating properties of NHE-1 and CAIX protect cells against irradiation.

\section{DUAL SILENCING OF THE HYPOXIA-INDUCED pH,-REGULATING- SYSTEM ca9/ca12 STRONGLY COMPROMISES IN VITRO AND IN VIVO TUMOR GROWTH WHEN COMBINED WITH IONIZING RADIATION}

LS174Tr cells cultured in hypoxia before exposure to an increasing dose of ionizing radiation demonstrated a higher cloning efficiency than normoxic cells along with equal distribution of cell cycle phases before irradiation (data not shown). This established the classical radioresistance of LS174Tr cells as observed in other hypoxic cells and validated this model for our study. In a regular $\mathrm{HCO}_{3}^{-}$-containing medium a higher number of cells in the radiosensitive $\mathrm{G} 1 / \mathrm{G} 2 / \mathrm{M}$ phases was observed when $c a 9$ or both $c a 9$ and cal2 were silenced (Figure 3A). Protein expression levels of CAIX and CAXII in the Tet-inducible silencing of $c a 9$ in control LS174Tr cells (LS-shca9/ctl) or ca12 silenced cells (LS-shca9/ca12- ) were confirmed for efficient knock-down (Figure 3A, inset). In the same conditions, ca9 or both $\mathrm{ca9} / \mathrm{cal} 2$ silencing was accompanied by an increase in p21, E-cadherin, and $\beta 1$ integrin expression, which were associated with a reduced cell proliferation (Figure 3B). To mimic both the tumor hypoxic and proton gradient observed in vivo, we grew LS174 cells in three dimensions. Spheroids were grown in nominally bicarbonate free media to enhance the $\mathrm{pH}$ gradients that develop during spheroid growth. Irradiation of ca9-silenced spheroids (LS-shca9/ctl + Tet, $8 \mathrm{~Gy}$ ) revealed a cumulative decrease in the proliferation index (Figure 3C) and a twofold increase in cell death from 27.5\% (0 Gy) to $51.7 \%$ ( $8 \mathrm{~Gy}$ ) when compared to non-irradiated $c a 9$-silenced spheroids (Figure 3D). While ca12 silencing alone did not alter 

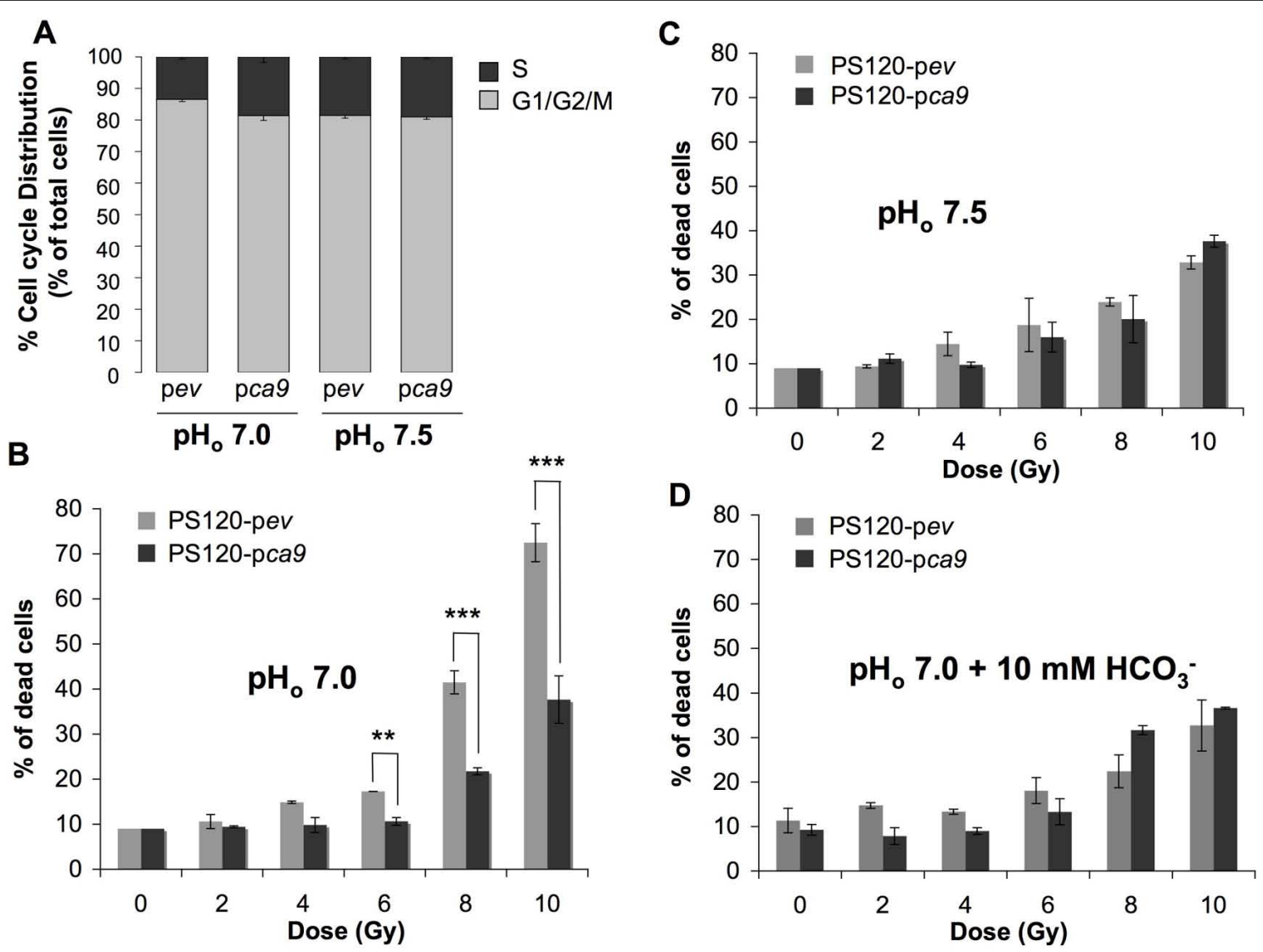

E

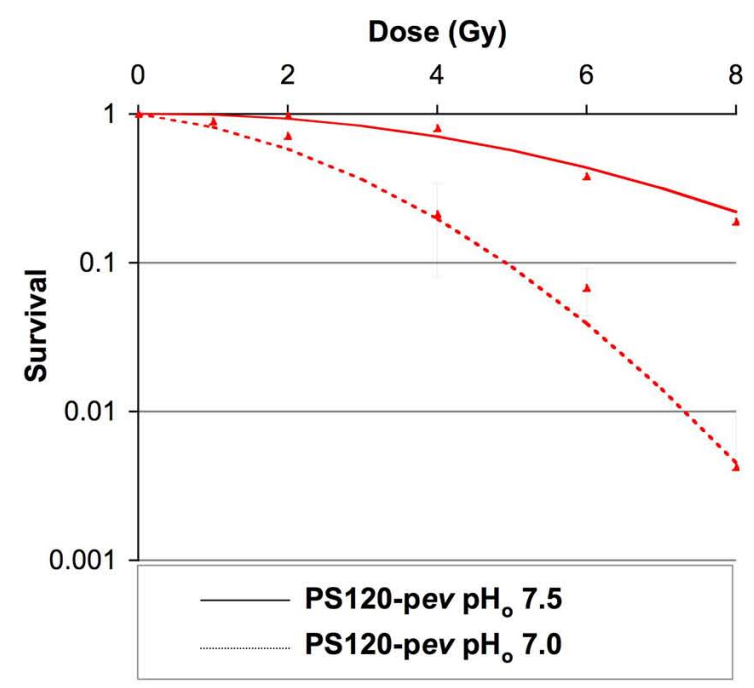

FIGURE 2 | CAIX protects cells against irradiation-induced cell death in an acidic environment. (A) Cell cycle distribution of NHE-1-disrupted fibroblasts PS120 cells expressing (pca9) or not (pev) CAIX, in normoxia in a $\mathrm{HCO}_{3}^{-} / \mathrm{CO}_{2}$-free environment at $\mathrm{pH}_{\mathrm{o}} 7.0$ or 7.5 for $24 \mathrm{~h}$. (B-D) PS120-pev and PS120-pca9 cells $\left(1 \times 10^{4}\right)$ were plated in $60 \mathrm{~mm}$ dishes. Once attached cells were incubated in $30 \mathrm{mM} \mathrm{HEPES}$-buffered $\mathrm{HCO}_{3}^{-}$-free medium adjusted to $\mathrm{pH}_{\circ} 7.0$ in the absence (B) or in the presence of $10 \mathrm{mM} \mathrm{HCO}_{3}^{-}$(D) or to $\mathrm{pH}_{\mathrm{O}} 7.5$ (C) for $24 \mathrm{~h}$ in a $\mathrm{CO}_{2}$-free atmosphere. Dishes were then irradiated $(0,2,4,6,8$, and $10 \mathrm{~Gy})$ and returned to a

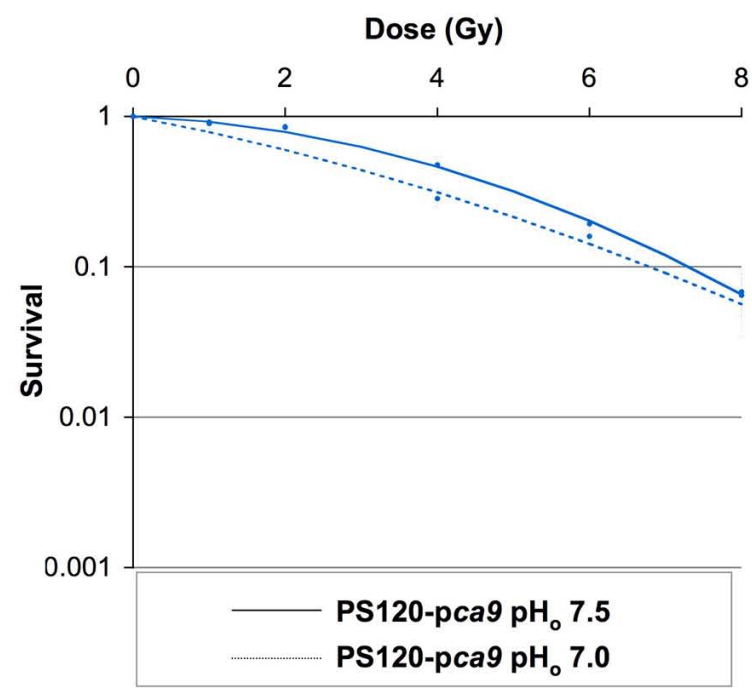

$\mathrm{CO}_{2}$-containing incubator with fresh regular $\mathrm{HCO}_{3}^{-}$-containing (44 mM) medium for 4 days. Cell death was determined by the trypan blue exclusion assay. Data represent the average of three independent experiments. (E) The clonogenic capacity of PS120-pev and PS120-pca9 cells exposed to a medium adjusted to $\mathrm{pH}_{\mathrm{O}} 7.0$ or 7.5 was measured 10 days after irradiation $(0,1,2,4,6$, and $8 \mathrm{~Gy})$. Dishes were stained with Giemsa (Fluka). The colonies were counted with ImageJ software according to the following parameters: particles size $=0.15-5 \mathrm{~mm}^{2}$ and circularity $=0.1-1$. 
A

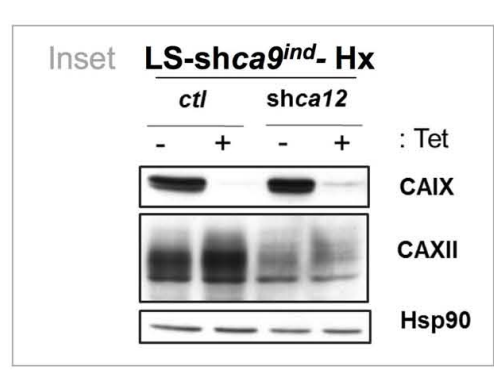

LS-shcagind-Hx

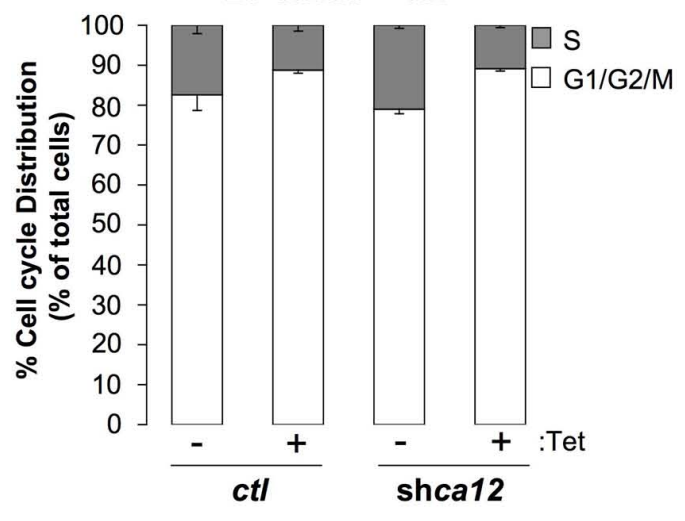

D

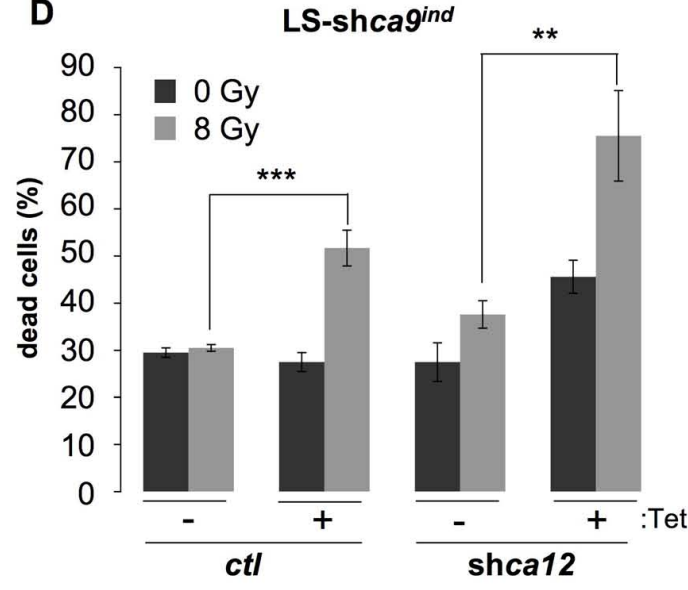

B

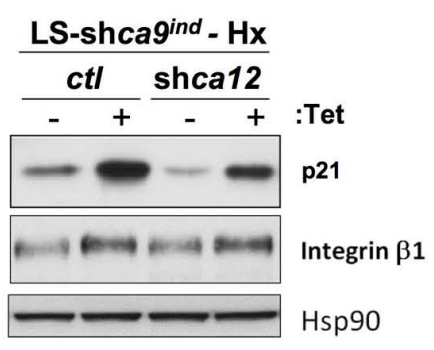

C

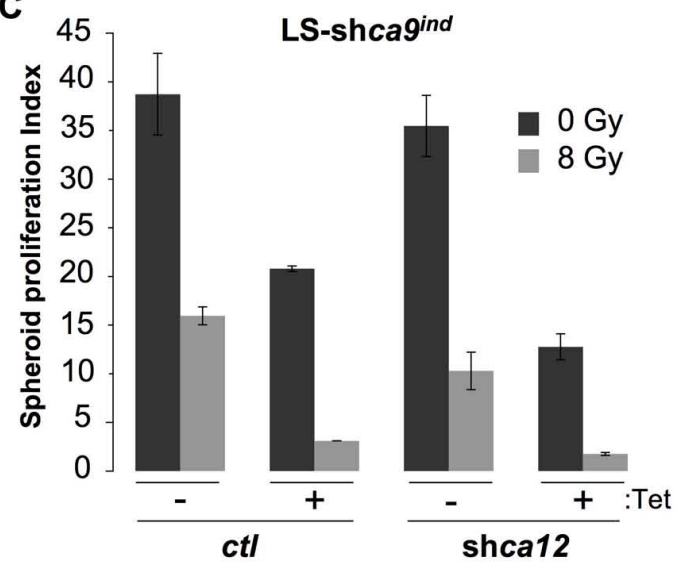

E

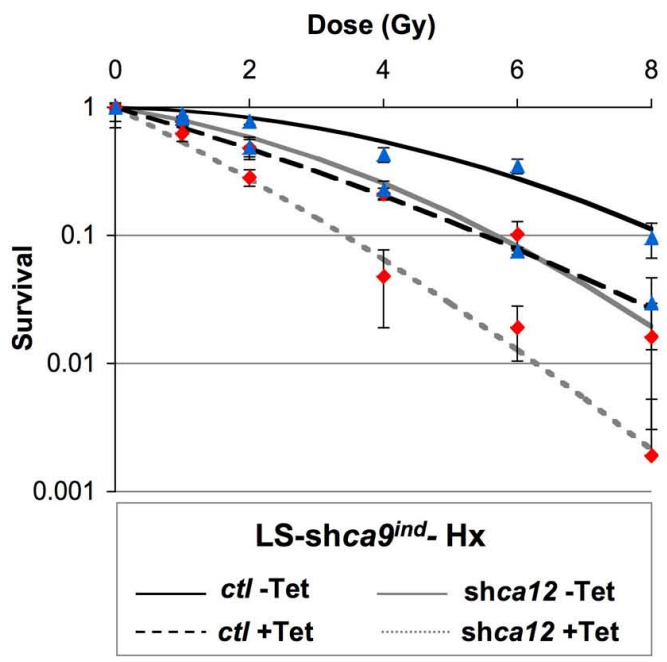

ca12 were cultured as spheroids in a $\mathrm{CO}_{2}$ atmosphere and HEPES-buffered $\mathrm{HCO}_{3}^{-}$-free medium $\left(\mathrm{pH}_{\circ} 7.7\right.$ in the absence (-Tet) or presence (+Tet) of Tet for 8 days before they were irradiated (8 Gy) or not (0 Gy). After irradiation, spheroids were transferred to polyhema-coated 96-well plates containing fresh medium for 5 days. Spheroids were then subjected to Accutase dissociation and individualized live cells (C) and dead cells (D) were counted using trypan blue. The spheroid proliferation index was calculated as the ratio of the number of living cells counted at day 13 to the number of cells at day 0 . Data represent the average of three independent experiments. (E) The clonogenic capacity of LS174Tr-shca9/ctl -/+Tet and LS174TR-shca9/ca12$-1+$ Tet cells exposed to hypoxia $\left(1 \% \mathrm{O}_{2}\right)$ for $48 \mathrm{~h}$ in a regular medium, was measured 10 days after irradiation $(0,1,2,4,6$, and 8 Gy). Dishes were stained with Giemsa (Fluka). The colonies were counted with Image $J$ software. 
the proliferation rate of non-irradiated spheroids, irradiation of ca12-silenced cells (LS-shca9/ca12- - Tet $8 \mathrm{~Gy}$ ) reduced the proliferation index (Figure 3C) and increased cell death from 27.5\% (0 Gy) to 37.6\% (8 Gy; Figure 3D). Irradiation of double silenced cells (LS-shca9/ca12- +Tet 8 Gy) strongly compromised proliferation and viability (75.5\% cell death; Figures 3C,D). Clonogenic test confirmed that double silenced cells (LS-shca9/cal2 $2^{-}+$Tet) exposed to hypoxia were less capable to recover from irradiation compared to control cells (LS-shca9/ctl -Tet) or single ca9 or ca12-silenced cells (LS-shca9/ctl + Tet and LS-shca9/ca12- - Tet; Figure 3E).

Using contact radiotherapy (Gérard et al., 2011), we specifically targeted the established tumor mass grown on the back of nude mice. Irradiation of control tumors (LS-shca9/ctl-DOX + IR) stopped tumor progression for 5 days after irradiation before proliferating again at a high rate, which was similar to that of non-irradiated control tumors (LS-shca9/ctl-DOX; Figure 4A). Tumor progression was delayed with $c a-9$-silencing as observed previously while irradiation of ca9-silenced tumors (LS-shca9/ctl $+\mathrm{DOX}+\mathrm{IR}$ ) showed more pronounced arrest in tumor progression (25 days after irradiation to reach $600 \mathrm{~mm}^{3}$ ), which may reflect cell death within the tumor (Figure 4A). Irradiation of cal2-silenced tumors (LS-shca9/cal2- - DOX +IR) reduced the growth rate compared to non-irradiated tumors (LS-sh $\mathrm{ca} 9 / \mathrm{cal}^{-}-\mathrm{DOX}$ ) to the same extent observed for irradiation of control tumors suggesting that cal2 alone is not able to confer tumor radioresistance (Figure 4B). However, irradiation of double silenced tumors (LS-shca9/ca12- + DOX +IR) showed a substantial reduction in the progression of the tumor (33 days after irradiation to reach $600 \mathrm{~mm}^{3}$ ). No interaction between DOX and irradiation was observed as shown with control LS-shev/ctl-/+DOX tumors (Figure 4C). Calculations of the tumor growth delay for time required to reach 300 and $600 \mathrm{~cm}^{3}$, respectively were 17.6/19.7 days (LS174shCA9 -Dox, -IR), 25.7 days/29.1 days (LS174shCA9 -Dox, +IR), 25.7 days/29 days (LS174shCA9 +Dox, -IR) and 36 days/46.3 days (LS174shCA9 + Dox, +IR). Growth delay times for CA9/CA12 double-silencing were 33.9 days/39.9 days (LS174shCA9/CA12 +Dox, -IR) and 36.1 days/45.9 days (LS174shCA9/CA12 + Dox, + IR). We further calculated the specific tumor growth delay (STGD) with the following formula: STGD $=(\mathrm{DT}$ experimental $-\mathrm{DT}$ control $) / \mathrm{DT}$ control (DT, doubling time). Irradiation alone and CA9 silencing alone resulted in similar STGD values of 0.61 and 0.57 , respectively. Combined irradiation and silencing of CA9 increased the STGD to 3.9 compared to control. Meanwhile silencing of CA12 resulted in a STGD value of 1.85 while double CA9 and CA12 silencing with irradiation had a similar STGD value to CA9 silencing of 3.67 .

These results demonstrate that silencing of ca9 and doublesilencing of $\mathrm{ca} 9 / \mathrm{ca} 12$ combined with ionizing radiation substantially decreases tumor growth in both in vitro and in vivo model systems.

\section{DISCUSSION}

Acidosis within the tumor microenvironment arises from the hypoxia-induced metabolic shift from oxidative phosphorylation to glycolysis, along with the capacity of hypoxic tumor cells to regulate their $\mathrm{pH}_{\mathrm{i}}$ through efficient export of $\mathrm{CO}_{2}$ and lactic acid. Consequently, targeting tumor $\mathrm{pH}_{\mathrm{i}}$-regulating systems in hypoxia holds potential as a key strategy to reduce tumor growth (Pouysségur et al., 2006). Here we have explored a combination of this $\mathrm{pH}$ disrupting strategy with radiotherapy as it was suggested that acidosis plays a role in tumor radioresistance (Vaupel, 2004). However, previously there was no clear demonstration whether the extracellular and/or the intracellular acidosis were responsible for the poor radioresponse of tumor cells. Dubois et al. (2011) have demonstrated that a combination of CAs inhibition with irradiation in colon HT29 tumor-bearing mice improved the anti-tumor effect compared to a single radiation dose. However, CA inhibition did not result in increased radiosensitivity in vitro and the contribution of the $\mathrm{pH}$-regulating functions of CAIX in the tumor radio-response remained to be clarified. Herein, we demonstrate the importance of $\mathrm{pH}_{\mathrm{i}}$ regulation in radioresistance by observing an increase in radiation-induced cell death of fibroblasts inhibited for NHE-1 or lacking both NHE-1 and CAIX when they are grown in an acidic and $\mathrm{HCO}_{3}^{-}$-free medium. In contrast, ectopic expression of CAIX was able to improve cell survival following irradiation. The mechanism of CAIX-induced radioresistance was demonstrated with NHE-1-deficient CCL39 fibroblasts (PS120 cells) in a nominally $\mathrm{CO}_{2} / \mathrm{HCO}_{3}^{-}$free acidic environment by: (i) a decrease in the $\mathrm{pH}_{\mathrm{i}}$-regulating capacity of cells lacking CAIX (see Chiche et al., 2009) and (ii) a correlation with the positioning of these cells in the most radiosensitive G1/G2/M phases, prior to irradiation. This cell cycle data is consistent with the reduction in S phase entry as previously demonstrated for PS120 cells compared to the parental cell line (Pouysségur et al., 1985). Expression of CAIX prevents the reduction of cells in S phase as it allows cells to maintain a higher $\mathrm{pH}_{\mathrm{i}}$ in acidic medium (Chiche et al., 2010a). With addition of $\mathrm{HCO}_{3}^{-} / \mathrm{CO}_{2}$ in low $\mathrm{pH}$ medium $\left(\mathrm{pH}_{\mathrm{o}} 7.0\right)$ we observed no difference in cell death between irradiated-PS120pev and irradiated-PS120-pca9 cells due to the buffering ability of $\mathrm{HCO}_{3}^{-} / \mathrm{CO}_{2}$ to restore alkaline $\mathrm{pH}_{\mathrm{i}}$ values as previously demonstrated (Chiche et al., 2010a). We conclude that the CAIX-induced protection against irradiation at $\mathrm{pH}_{\mathrm{o}} 7.0$ could be explained by the capacity of CAIX to sustain an intracellular alkaline shift.

Under three-dimensional growth conditions that result in hypoxia (Chiche et al., 2010a; Pelletier et al., 2012) and acidosis (Swietach etal., 2010), LS174Tr spheroids silenced for ca9/ca12 showed a decrease in proliferation and a cumulative increase in cell death $(75 \%)$ after a single radiation dose. Double silenced cells were indeed most sensitive to irradiation, since: (i) combined silencing reduced the capacity of LS174Tr cells to regulate their $\mathrm{pH}_{\mathrm{i}}$ in acidic medium while single silencing of $c a 9$ was not sufficient to do so (Chiche et al., 2010a), (ii) silencing of ca9/ca12 increased p21 expression indicating a cell cycle arrest in G1 along with increased levels of $\beta 1$ integrin, two key proteins involved in cell contact and adhesion which may influence proliferation (Svastová et al., 2003) and (iii) ca9 silencing lead to a reduction in proliferation and a decrease in cell number in the radioresistant $S$ phase. A single radiation dose on xenograft tumors dramatically reduced the growth rate of $c a 9$ - and ca9/cal2-silenced tumors. Twenty-five days after irradiation, $c a 9$-silenced tumors recovered a growth rate that was comparable to control tumors, while ca9/cal2-silenced 
A

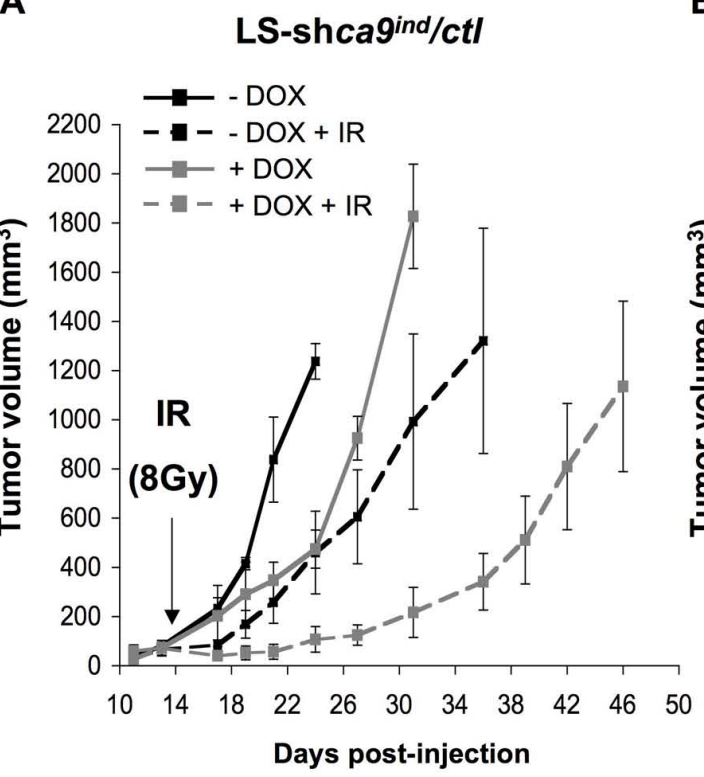

B

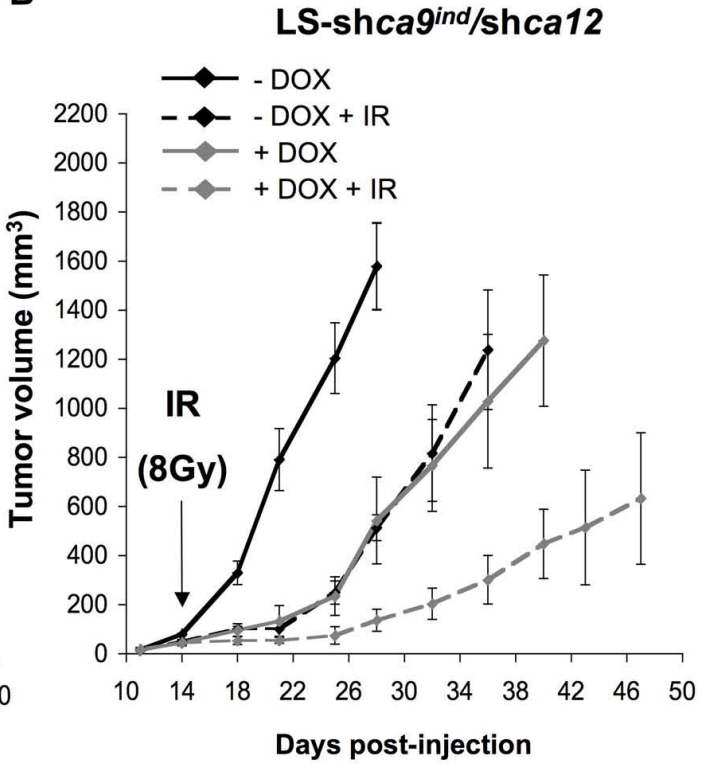

C

\section{LS-shevind/ctl}

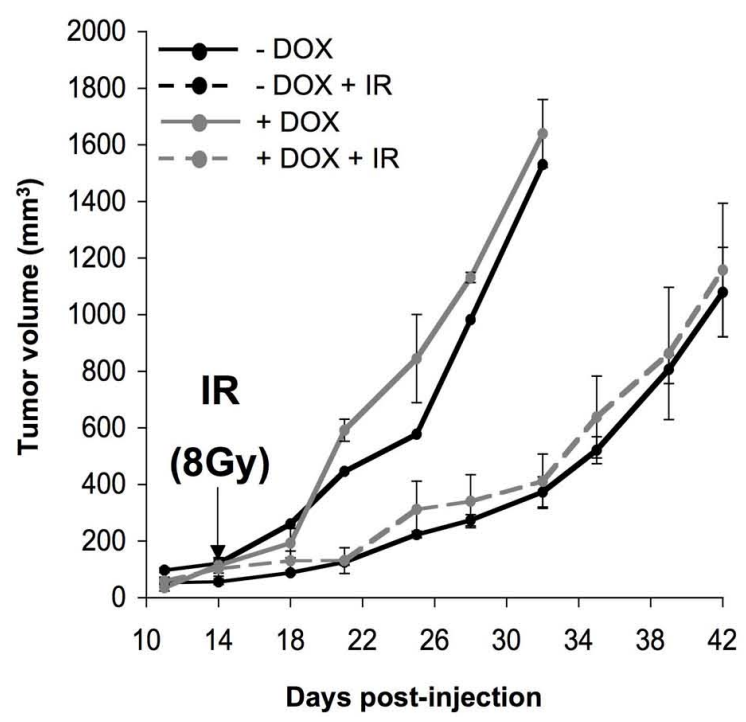

FIGURE 4 | Combined silencing of ca9 and ca 12 compromises in vivo LS174Tr cell proliferation when combined with ionizing radiation. $(\mathbf{A}, \mathbf{B})$. Anti-tumor activity of silencing ca9 or ca12 individually or combined is increased in conjunction with ionizing radiation in LS174Tr xenograft tumors. At 4 days before injection of LS-shca9/ctl (A) or LS-shca9/ca12- cells (B), cells were incubated with or without Tet (+/-Tet) to silence ca9. In vivo xenograft assays were performed by s.c injection of viable and individual tumor cells $\left(1 \times 10^{6}\right)$ into the flanks of athymic nude mice. To maintain ca9 knock-down mice received DOX in the drinking water 4 days before cell injection. Fifteen days after cell injection, when the tumor size reached 4-5 mm, a single dose (8 Gy) of irradiation (IR) was delivered to the tumors only with "contact X-rays." Xenograft growth was determined by measuring the tumor volume. (C) Xenograft tumor growth of control tumors LS-shev/ctl irradiated (IR) or not, in the presence (+DOX) or in the absence (-DOX) of doxycycline in the drinking water. Five mice were used per condition. and irradiated tumors never recovered the growth rate of control cells. In addition, the loss of radioresistant hypoxic cells due to CA9/CA12 silencing could contribute to the reduction of tumor growth in combination with their radio-sensitivity due to decreased $\mathrm{pH}_{\mathrm{i}}$ regulation.
Hypoxia-specific cytotoxins such as tirapazamine form toxic radical species that act to kill hypoxic cells and are thus proposed to be used in combination with irradiation to create a synergistic effect (Brown, 1993). Unfortunately this treatment-strategy failed to be efficient in patients (Rischin et al., 2010). Intense research 
is ongoing in the development of small molecule inhibitors to specifically target membrane-bound CA(s) over cytosolic CAs to appraise the potential of targeting CAIX and CAXII to decrease tumor progression (Morris etal., 2011). The synthesis of new CA(s) inhibitors (Supuran, 2008; Morris et al., 2011) has also revived interest in acetazolamide (ACTZ), which has been used in the clinic for over 40 years as a CA inhibitor (Kaur et al., 2002). Recently, ACTZ was linked to a C-terminal albuminbinding peptide (Albu-ACTZ) with the aim of not only reducing blood clearance but also preventing internalization of the molecule to target more specifically membrane-bound CAIX and CAXII. This compound demonstrated its in vivo efficacy by retarding tumor growth of renal SK-RC-52 xenografts. However, it had no significant impact on highly proliferative LS174Tr tumors (Ahlskog et al., 2009).

In the present study, we took advantage of the expression of the hypoxia-induced $\mathrm{pH}_{\mathrm{i}}$-regulating systems CAIX and CAXII to

\section{REFERENCES}

Ahlskog, J. K., Dumelin, C. E., Trüssel, S., Mårlind, J., and Neri, D. (2009). In vivo targeting of tumor-associated carbonic anhydrases using acetazolamide derivatives. Bioorg. Med. Chem. Lett. 19, 4851-4856.

Brown, J. M. (1993). SR 4233 (tirapazamine): a new anticancer drug exploiting hypoxia in solid tumours. Br. J. Cancer 67, 1163-1170.

Brown, J. M. (2007). Tumor hypoxia in cancer therapy. Methods Enzymol. 435, 297-321.

Chiche, J., Brahimi-Horn, M. C., and Pouysségur, J. (2010a). Tumour hypoxia induces a metabolic shift causing acidosis: a common feature in cancer. J. Cell. Mol. Med. 14, 771-794.

Chiche, J., Ilc, K., Brahimi-Horn, M. C., and Pouysségur, J. (2010b). Membrane-bound carbonic anhydrases are key $\mathrm{pH}$ regulators controlling tumor growth and cell migration. Adv. Enzyme Regul. 50, 20-33.

Chiche, J., Ilc, K., Laferrière, J., Trottier, E., Dayan, F., Mazure, N. M., et al. (2009). Hypoxia-inducible carbonic anhydrase IX and XII promote tumor cell growth by counteracting acidosis through the regulation of the intracellular pH. Cancer Res. 69 , 358-368.

Darby, S., Mcgale, P., Correa, C., Taylor, C., Arriagada, R., Clarke, M., et al. (2011). Effect of radiotherapy after breast-conserving surgery on 10-year recurrence and 15-year breast cancer death: meta-analysis of individual patient data for 10,801 women in 17 randomised trials. Lancet 378, 1707-1716.

Deschner, E. E., and Gray, L. H. (1959). Influence of oxygen tension on $\mathrm{x}$ ray-induced chromosomal damage in Ehrlich ascites tumor cells irradiated in vitro and in vivo. Radiat. Res. 11, 115-146.

Dewey, D. L. (1960). Effect of oxygen and nitric oxide on the radiosensitivity of human cells in tissue culture. Nature 186, 780-782.

Dubois, L., Peeters, S., Lieuwes, N. G., Geusens, N., Thiry, A., Wigfield, S., et al. (2011). Specific inhibition of carbonic anhydrase IX activity enhances the in vivo therapeutic effect of tumor irradiation. Radiother. Oncol. 99, 424-431.

Gérard, J. P., Myint, A. S., Croce, O., Lindegaard, J., Jensen, A., Myerson, R., et al. (2011). Renaissance of contact x-ray therapy for treating rectal cancer. Expert Rev. Med. Dev. 8, 483-492.

Gray, L. H. (1953). The initiation and development of cellular damage by ionizing radiations; the thirtysecond Silvanus Thompson Memorial Lecture. $B r$. J. Radiol. 26, 609-618.

Grotius, J., Dittfeld, C., Huether, M., Mueller-Klieser, W., Baumann, M., and Kunz-Schughart, L. A. (2009). Impact of exogenous lactate on survival and radioresponse of carcinoma cells in vitro. Int. J. Radiat. Biol. 85, 989-1001.

Halestrap, A. P., and Price, N. T. (1999). The proton-linked monocarboxylate transporter (MCT) family: structure, function and regulation. Biochem. J. 343, 281-299.

Huen, M. S., and Chen, J. (2008). The DNA damage response pathways: at the crossroad of protein modifications. Cell Res. 18, 8-16.

Hwang, H. S., Davis, T. W., Houghton, J. A., and Kinsella, T. J. (2000). Radiosensitivity of thymidylate synthase-deficient human tumor cells is affected by progression through the G1 restriction point into

target radioresistant hypoxic cells. This study reinforces the notion that CAIX and CAXII represent potential targets for anti-cancer treatment. The present study also supports the use of radiotherapy in combination with CAs inhibition as a new anti-cancer strategy.

\section{ACKNOWLEDGMENTS}

The laboratory is funded by the Ligue Nationale Contre le Cancer (Equipe labellisée), the EU-FP7-"METOXIA," the Association pour la Recherche contre le Cancer, the Institut National du Cancer, the Agence Nationale pour la Recherche, the Centre Antoine Lacassagne, the Centre National de la Recherche Scientifique, the Institut National de la Santé et de la Recherche Médicale, and the University of Nice. Scott K. Parks was funded by The Natural Sciences and Engineering Research Council of Canada (NSERC) and the Association pour la Recherche contre le Cancer (ARC). Johanna Chiche was funded by the "METOXIA" grant and the ARC.

S-phase: implications for fluoropyrimidine radiosensitization. Cancer Res. 60, 92-100.

Jackson, S. P., and Bartek, J. (2009). The DNA-damage response in human biology and disease. Nature 461, 1071-1078.

Kastan, M. B., and Bartek, J. (2004). Cell-cycle checkpoints and cancer. Nature 432, 316-323.

Kaur, I. P., Smitha, R., Aggarwal, D., and Kapil, M. (2002). Acetazolamide: future perspective in topical glaucoma therapeutics. Int. J. Pharm. 248, $1-14$.

Masereel, B., Pochet, L., and Laeckmann, D. (2003). An overview of inhibitors of $\mathrm{Na}(+) / \mathrm{H}(+)$ exchanger. Eur. J. Med. Chem. 38, 547-554.

Morgan, P. E., Pastoreková, S., StuartTilley, A. K., Alper, S. L., and Casey, J. R. (2007). Interactions of transmembrane carbonic anhydrase, CAIX, with bicarbonate transporters. Am. J. Physiol. Cell Physiol. 293, C738-C748.

Morris, J. C., Chiche, J., Grellier, C., Lopez, M., Bornaghi, L. F., Maresca, A., et al. (2011). Targeting hypoxic tumor cell viability with carbohydrate-based carbonic anhydrase IX and XII inhibitors. J. Med. Chem. 54, 6905-6918.

Parks, S. K., Chiche, J., and Pouysségur, J. (2011). pH control mechanisms of tumor survival and growth. J. Cell. Physiol. 226, 299-308.

Pastoreková, S., Parkkila, S., Parkkila, A. K., Opavsky, R., Zelnik, V., Saarnio, J., et al. (1997). Carbonic anhydrase IX, MN/CA IX: analysis of stomach complementary DNA sequence and expression in human and rat alimentary tracts. Gastroenterology 112 , 398-408.

Pawlik, T. M., and Keyomarsi, K. (2004). Role of cell cycle in mediating sensitivity to radiotherapy. Int. J. Radiat. Oncol. Biol. Phys. 59, 928-942.

Pelletier, J., Dayan, F., Durivault, J., Ilc, K., Pécou, E., Pouysségur, J., etal. (2012). The asparaginyl hydroxylase factor-inhibiting HIF is essential for tumor growth through suppression of the p53-p21 axis. Oncogene 31, 2989-3001.

Pouysségur, J., Dayan, F., and Mazure, N. M. (2006). Hypoxia signalling in cancer and approaches to enforce tumour regression. Nature 441, 437-443.

Pouysségur, J., Franchi, A., L'allemain, G., and Paris, S. (1985). Cytoplasmic $\mathrm{pH}$, a key determinant of growth factor-induced DNA synthesis in quiescent fibroblasts. FEBS Lett. 190, 115-119.

Pouysségur, J., Sardet, C., Franchi, A., L'Allemain, G., and Paris, S. (1984). A specific mutation abolishing $\mathrm{Na}^{+} / \mathrm{H}^{+}$antiport activity in hamster fibroblasts precludes growth at neutral and acidic $\mathrm{pH}$. Proc. Natl. Acad. Sci. U.S.A. 81, 48334837.

Quennet, V., Yaromina, A., Zips, D., Rosner, A., Walenta, S., Baumann, M., et al. (2006). Tumor lactate content predicts for response to fractionated irradiation of human squamous cell carcinomas in nude mice. Radiother. Oncol. 81, 130-135.

Rischin, D., Peters, L. J., O'Sullivan, B., Giralt, J., Fisher, R., Yuen, K., et al. (2010). Tirapazamine, cisplatin, and radiation versus cisplatin and radiation for advanced squamous cell carcinoma of the head and neck (TROG 02.02, HeadSTART): a phase III trial of the Trans-Tasman Radiation Oncology Group. J. Clin. Oncol. 28, 29892995. 
Romero, M. F., Fulton, C. M., and Boron, W. F. (2004). The SLC4 family of $\mathrm{HCO}_{3}^{-}$transporters. Pflugers Arch. $447,495-509$.

Supuran, C. T. (2008). Carbonic anhydrases: novel therapeutic applications for inhibitors and activators. Nat. Rev. Drug Discov. 7, 168-181.

Svastová, E., Hulíková, A., Rafajová, M., Zat'ovicova, M., Gibadulinova, A., Casini, A., et al. (2004). Hypoxia activates the capacity of tumorassociated carbonic anhydrase IX to acidify extracellular pH. FEBS Lett. 577, 439-445.

Svastová, E., Zilka, N., Zat'ovicová, M., Gibadulinová, A., Ciampor, F., Pastorek, J., et al. (2003). Carbonic anhydrase IX reduces E-cadherinmediated adhesion of MDCK cells via interaction with beta-catenin. Exp. Cell Res. 290, 332-345.

Swietach, P., Hulikova, A., VaughanJones, R. D., and Harris, A. L. (2010). New insights into the physiological role of carbonic anhydrase IX in tumour $\mathrm{pH}$ regulation. Oncogene 29, 6509-6521.

Swietach, P., Patiar, S., Supuran, C. T., Harris, A. L., and Vaughan-Jones, R. D. (2009). The role of carbonic anhydrase 9 in regulating extracellular and intracellular ph in three-dimensional tumor cell growths. J. Biol. Chem. 284, 20299-20310.

Vaupel, P. (2004). Tumor microenvironmental physiology and its implications for radiation oncology. Semin. Radiat. Oncol. 14 198-206.
Wykoff, C. C., Beasley, N. J., Watson, P. H., Turner, K. J., Pastorek, J., Sibtain, A., et al. (2000). Hypoxia-inducible expression of tumor-associated carbonic anhydrases. Cancer Res. 60 7075-7083.

Conflict of Interest Statement: The authors declare that the research was conducted in the absence of any commercial or financial relationships that could be construed as a potential conflict of interest.

Received: 01 September 2012; paper pending published: 20 September 2012; accepted: 07 December 2012; published online: 07 January 2013.
Citation: Doyen J, Parks SK, Marcié S, Pouysségur J and Chiche J (2013) Knock-down of hypoxia-induced carbonic anhydrases IX and XII radiosensitizes tumor cells by increasing intracellular acidosis. Front. Oncol. 2:199. doi: 10.3389/fonc.2012.00199

This article was submitted to Frontiers in Molecular and Cellular Oncology, a specialty of Frontiers in Oncology.

Copyright (c) 2013 Doyen, Parks, Marcié, Pouysségur and Chiche. This is an open-access article distributed under the terms of the Creative Commons Attribution License, which permits use, distribution and reproduction in other forums, provided the original authors and source are credited and subject to any copyright notices concerning any thirdparty graphics etc. 